\title{
Analysis of needs for the development of trainer sensor and transducer learning media based on Internet of Things (IoT)
}

\author{
Purnamawati Purnamawati (D), Muhammad Akil * (D), Nuridayanti Nuridayanti \\ Universitas Negeri Makassar, Indonesia. \\ * Corresponding Author. Email: muhammadakil@unm.ac.id
}

\section{ARTICLE INFO}

\section{Article History}

Received:

14 September 2021;

Revised:

14 November 2021;

Accepted:

19 December 2021,

Available online:

4 January 2022

\section{Keywords}

Instructional media

trainer;

Internet of Things;

Needs analysis;

Sensors and

Transducers

\begin{abstract}
The purpose of this study was to analyze the needs of students and teachers in developing a learning media in the form of a trainer to support the sensor and transducer practicum process during the Covid-19 Pandemic. This type of research is quantitative research with descriptive statistical analysis techniques. Data were collected through questionnaires distributed online to 75 respondents, including productive electronic engineering and electrical engineering teachers at SMK Negeri 2 and SMK Negeri 10 Makassar and their students. In addition, there were also respondents from electronic engineering students at the two schools. This study indicates that facilities and infrastructure in schools are in the high category with a percentage of $64 \%$. Learning conditions during the Covid-19 Pandemic based on data from respondents are in the medium category with a percentage of $67 \%$. The level of need for IoT-based sensor trainer learning media to support distance learning at SMK Negeri 2 Makassar and SMK Negeri 10 Makassar is in the high category with a percentage of $72 \%$. Based on this value, it can be concluded that practicum facilities are needed in the form of IoT-based sensors and transducer trainers that can be used as alternative learning during the Covid-19 Pandemic. It is hoped that the teachers can adjust learning tools according to pandemic conditions so that the implementation of the learning process can run smoothly.
\end{abstract}

This is an open access article under the CC-BY-SA license.

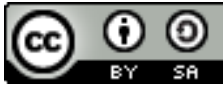

How to cite:

Purnamawati, P., Akil, M., \& Nuridayanti, N. (2021). Analysis of needs for the development of trainer sensor and transducer learning media based on Internet of Things (IoT). Jurnal Pendidikan Vokasi, 11(3), $232-242$.

https://doi.org/10.21831/jpv.v11i3.43833

\section{INTRODUCTION}

The need for media in learning is very important to ensure the achievement of learning objectives for students (Nurrita, 2018). Media is a tool used to assist the learning process and is generally mentioned in the learning design, so educators must have the ability to design and implement quality learning as a factor in improving the quality of learning quality (Yaumi, 2018). In addition, educators are expected to have sensitivity to all conditions experienced by students so that they do not quickly cause an unpleasant atmosphere for students. An educational paradigm that is recommended in learning is to use Student-Centered Learning (SCL) methods. The use of the SCL method in learning has proven to have a very good impact on students. This can be seen in various studies using SCL with very effective results in increasing student understanding (Marpaung \& Azzajjad, 2020), giving students confidence in carrying out the learning process (Mariana, 2020), and can improve students' skills from the results of their learning activities (Zaus et al., 2019). 
In addition to student-centered learning, blended learning is becoming popular amid the current development of information technology. Mixed learning is an innovative concept that combines face-to-face meetings or traditional learning with online learning (with the help of ICT) (Lalima \& Dangwal, 2017). Mixed learning is very suitable for use in learning activities during the pandemic, although online meetings are mostly conducted to prevent the transmission of Covid-19. According to Allen et al. (2007), online learning can be carried out with a proportion of $30-79 \%$ in mixed learning, where the substance of delivering material and giving assignments is mostly carried out online.

Unlike the case for practical learning, during the current pandemic, government regulation requires all work to be carried out at home, including schools. This is, of course, to prevent the spread of Covid-19. Based on these conditions, practicum subjects become a big problem for some teachers because they have to make various efforts to find ways to achieve practicum objectives, including using several learning methods. Of course, the use of a good method cannot be separated from the media or learning tools used. In general, in practical learning, media trainers are very suitable and needed in several schools and vocational colleges in Indonesia. The learning outcomes of students who use trainer media in several practicum subjects in vocational high schools have been shown to increase, as was done by Rahmadiyah and Sumbawati (2014) with the results of the cognitive assessment of students getting a very good category after using the trainer as a media on basic electronics engineering subjects at SMK Kartika 2 Surabaya. Arifin and Zuhrie (2015) did the same thing and Hariyadi and Kholis (2015), which got a positive response or very good category from students after using a microcontroller trainer media.

In the example of the sensor and transducer practicum case, the appropriate practicum media used is the sensor and transducer trainer (Purnamawati et al., 2021). The use of sensor and transducer trainers is effective and feasible to use based on the research results obtained, namely student responses to the use of sensor and transducer trainers in practicum reaching a very good category. However, this research has not been equipped with Internet of Things (IoT) technology so that its application is carried out face-to-face.

The use of IoT technology strongly supports the online learning process, especially in practicum during the pandemic. The utilization of the internet network makes data communication possible without the limitations of distance and time. Thus, the process of reading sensor values can be carried out at a long distance (in this case, at the student's house) either through the android application or web browser. So that practical activities can be carried out remotely in terms of monitoring and controlling sensor and transducer equipment.

The availability of IoT kits or modules that can be used for the learning process is currently on sale. Not even a few of the student's final projects are implementing IoT. However, there are several problems: the lack of students' understanding of making hardware like a minimum microcontroller system and any other input-output equipment that connects to it. The added lacks are the students didn't understand how to connect the microcontroller with communication media and how to create a network as cloud IoT, even to create an interface platform to the web or Android application that makes it easier for users to access the equipment (Hariyanto et al., 2020). Based on these problems, Rahayu et al. (2020) tried to make an IoT-based trainer to increase teachers' understanding of IoT and to be able to apply the trainer to the learning process for students. Hasanah et al. (2018) has also done the same thing, who made an IoT trainer support IoT practical learning. Online system learning in practicum has also been carried out by Jarillo et al. (2019) by developing a virtual laboratory that can be controlled remotely by offering an online laboratory.

This study aims to obtain important information and analyze data related to the needs of teachers and students in developing IoT trainer learning media products on sensors and transducer subjects at vocational schools in Makassar. Through this research, it is hoped that teachers can make the right decisions in compiling the learning process according to user requests. 


\section{RESEARCH METHOD}

This research is a quantitative descriptive study that will describe the learning conditions in partner schools and analyze the needs of learning media in supporting distance learning. The samples in this study were productive teachers of electronics engineering and several students from SMK Negeri 2 and SMK Negeri 10 Makassar. The sample selection was made randomly, especially for students. The data collection was carried out by distributing online questionnaires through the Google Forms application on a number of samples.

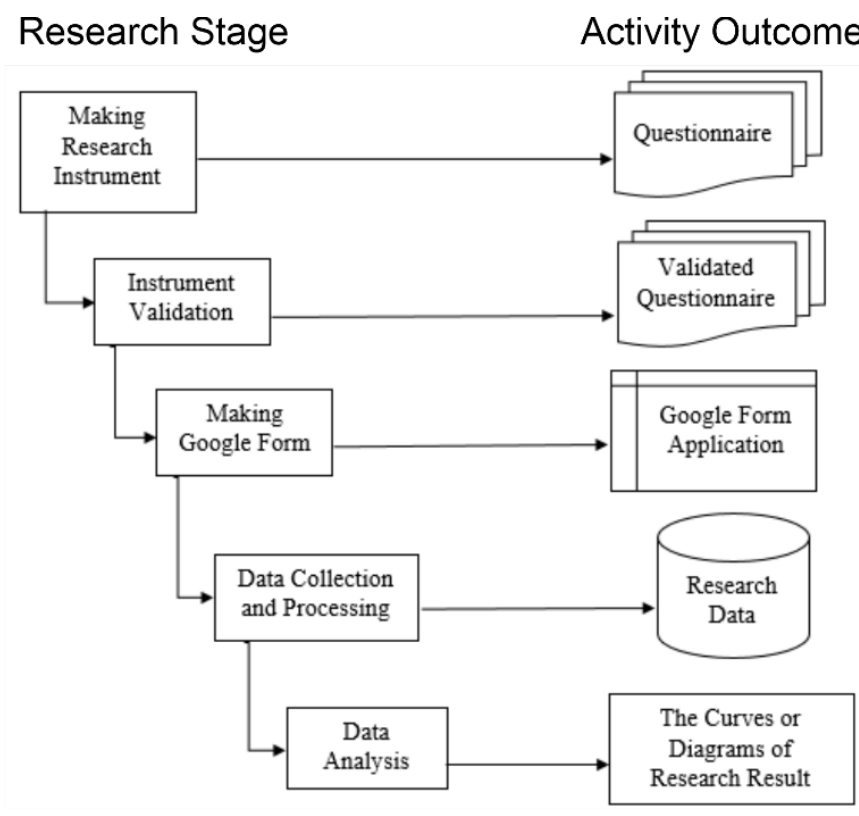

Figure 1. Research Stages

Based on the information shown in Figure 1, the first stage is making research instruments. The research instrument is made in the form of a statement that explores the necessary research information and what products need to be developed in overcoming problems at school. The research instrument consisted of 3 main indicators, namely the condition of facilities and infrastructure, learning conditions, and media needs. The instrument was then validated by a media expert validator consisting of four people with study backgrounds from electrical and electronic engineering education. The validation results are then processed using Aiken $\mathrm{V}$ to see the results per item using Formula 1 (Aiken, 1985; Azwar, 2016).

$$
V=\frac{\sum s}{n(c-1)}
$$

Descriptions:

$$
\begin{aligned}
& \mathrm{S}=\mathrm{r}-\mathrm{lo} \\
& \mathrm{Lo}=\text { The lowest score of validity assessment } \\
& \mathrm{c}=\text { The highest score of validity assessment } \\
& \mathrm{r}=\text { Score given by validator } \\
& \mathrm{n}=\text { Sum of experts \& practitioners who do an assessment }
\end{aligned}
$$

Aiken proposes the concept of content validity in more detail, especially detailed on standard validity, which is influenced by the number of raters and the rating scale used (Aiken, 1985). The next stage is making a google form application. This research activity was carried out still in a pandemic atmosphere so that the implementation process was carried out online and offline. The research questionnaires were distributed through the Google Form application to 75 respondents consisting of 24 teachers and 51 students. The next stage is the collection and processing of data from respondents. The data collected contains information from respondents directly and is processed 
for data analysis purposes. The items of the instruments used can be seen in Table 1, Table 2, and Table 3. The data that has been obtained are categorized according to Azwar (2010) as can be seen in Table 4.

Table 1. Instruments for the Condition of Facilities and Infrastructure

\begin{tabular}{cl}
\hline No. & \multicolumn{1}{c}{ Statement Items } \\
\hline 1. & Distance Learning Activities, which are government policies in the new normal period of covid 19, \\
2. & Availability of laboratory facilities in schools as a place for students to practice . \\
3. & Availability of practicum facilities in the form of trainers that support distance learning \\
4. & The use of trainer learning media can increase students' interest and motivation to learn. \\
5. There is an internet network at school and at home that supports distance learning activities & There are supporting equipment for the implementation of distance learning such as mobile phones \\
6. & and laptops
\end{tabular}

Table 2. Instrument of Learning Conditions

\begin{tabular}{cl}
\hline No. & \multicolumn{1}{c}{ Statement Items } \\
\hline 1. & During the implementation of distance learning, students are actively involved in learning activities \\
2. & Teachers and students have no difficulty in implementing distance learning \\
3. & Traditional learning by only focusing on teacher explanations can be easily understood by students \\
4. & One method of distance learning in practical subjects can be carried out by means of simulation \\
5. & Simulation-based practicum activities are sufficient to increase understanding of the material provided \\
6. & Student learning outcomes for practical subjects during the distance learning period have decreased \\
7. & Student learning outcomes for practical subjects during the distance learning period have increased \\
\hline
\end{tabular}

Table 3. Instruments for Learning Media Needs to Support Distance Learning

\begin{aligned} & \hline No. \multicolumn{1}{c}{ Statement Items } \\ & \hline 1. Practical activities carried out with only simulations have not been effective without trainer learning \\ & 2. Practicum activities using a media trainer are needed \\ & 3. One of the trainer learning media that supports distance learning is an IoT-based trainer \\ & 4. IoT-based practicum activities can be carried out at students' homes during the practical learning \\ & process \\ & 5. IoT-based home practicum activities can increase students' learning motivation, especially in remote \\ & control material for components used in media trainers. \\ & 6. Understanding and analyzing the characteristics of sensor and transducer components through practice \\ & 7rom home can increase learning motivation \\ & T. The use of IoT technology in remote practice can be done to read sensor values on trainer learning \\ & \hline\end{aligned}

Table 4. Interval Category

\begin{tabular}{cc}
\hline Interval & Category \\
\hline$X<(\mu-1,0 \sigma)$ & Low \\
$(\mu-1,0 \sigma) \leq X<(\mu+1,0 \sigma)$ & Medium \\
$(\mu+1,0 \sigma) \leq X$ & High \\
\hline
\end{tabular}

Descriptions:

$\mathrm{X}=$ Score

$\mu=$ Mean ideal $=1 / 2$ (highest score + lowest score)

$\sigma=$ Ideal Standard Deviation

$\sigma=1 / 6$ (highest score - lowest score) 


\section{RESULT AND DISCUSSION}

Result

This research was conducted to determine the need for trainer learning media on sensor and transducer material at SMK Negeri 2 Makassar and SMK Negeri 10 Makassar in order to support the implementation of distance learning. Three indicators will be explored in the questionnaire that has been distributed to teachers and students. The scores obtained from the results of the expert validity test on the instrument items were analyzed using the Aiken $\mathrm{V}$ validity analysis. The analysis results were valid or invalid categories based on the Aiken V coefficient. Based on the Table 4, the value of the coefficient of validity (V) on a rating scale of 5 with four raters is 0.88 (Aiken, 1985). Therefore, all types of instruments in the three indicators are declared valid with an average score of 0.90 . The average score of V Aiken can be seen in Figure 2.

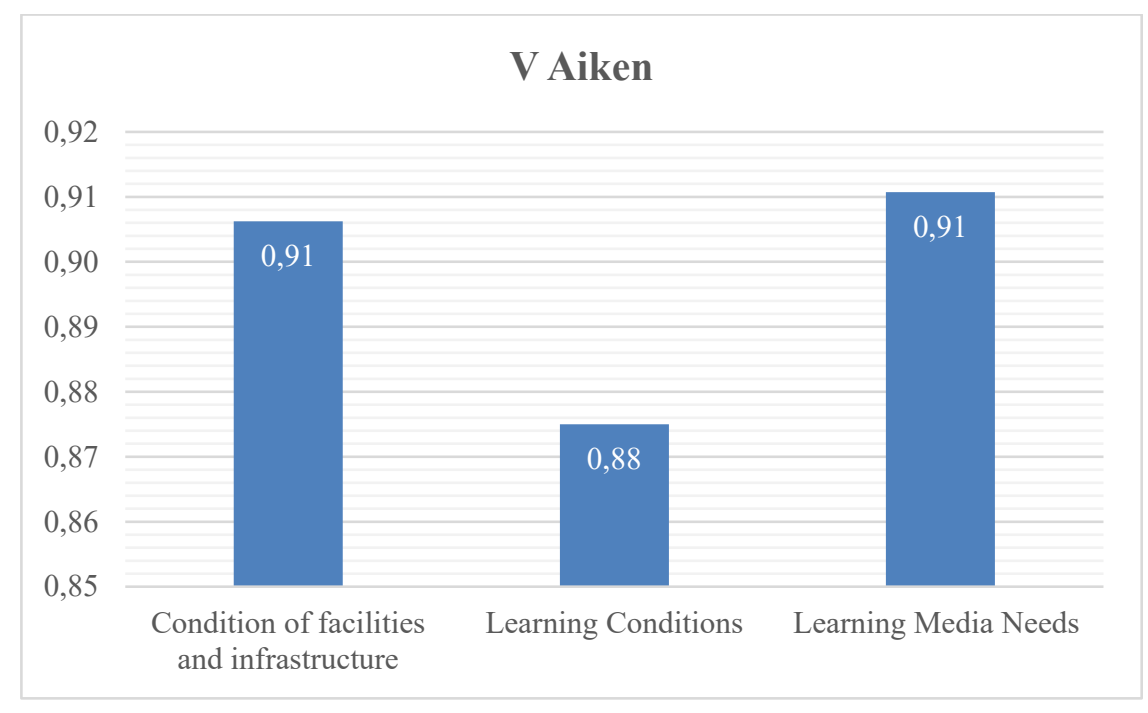

Figure 2. V Aiken's Average Score

\section{Condition of facilities and infrastructure}

The condition of facilities and infrastructure indicator consists of 6 question items: 1.) The challenges of distance learning; 2.) The availability of laboratory facilities; 3.) The availability of practical facilities in the form of trainers; 4.) The use of trainers in learning; 5.) The availability of internet networks in schools; and 6.) The availability of distance learning support equipment such as laptops and smartphones. The learning media requirement interval is determined by first determining the maximum data, minimum data, range, standard deviation, and theoretical mean. The data from the descriptive analysis can be seen in Table 5. Based on the data in Table 5, the interval category can be determined by substituting it into the predetermined criteria.

Table 5. The Results of the Descriptive Analysis of the Condition of Learning Facilities and Infrastructure

\begin{tabular}{cccccc}
\hline Number of Respondents & Mean $(\mu)$ & Std. deviation $(\sigma)$ & Range & Minimum & Maximum \\
\hline 75 & 15 & 3 & 18 & 6 & 24 \\
\hline
\end{tabular}

The data in Table 6 shows that respondents who have a questionnaire score of less than 12 state that the condition of facilities and infrastructure to support the implementation of distance learning is in a low category. Respondents who had a questionnaire score ranging from 12 to less than 18 stated that the condition of the facilities' implementation of distance learning was in the medium category. Meanwhile, respondents who have a questionnaire score equal to or greater than 
18 state the condition of the facilities and infrastructure to support their implementation of distance learning is in the high category.

Table 6. Frequency Distribution of Facilities and Infrastructure Conditions

\begin{tabular}{ccccc}
\hline Formula & Interval & Category & Frequency & Percentage \\
\hline $\mathrm{X}<\{15-1,0(3)\}$ & $\mathrm{X}<12$ & Low & 2 & $2,67 \%$ \\
$\{15-1,0(3)\} \leq \mathrm{X}<\{15+1,0(3)\}$ & $12 \leq \mathrm{X}<18$ & Medium & 25 & $33,33 \%$ \\
$\{15+1,0(3)\} \leq \mathrm{X}$ & $18 \leq \mathrm{X}$ & High & 48 & $64 \%$ \\
& Total & & & $100 \%$ \\
\hline
\end{tabular}

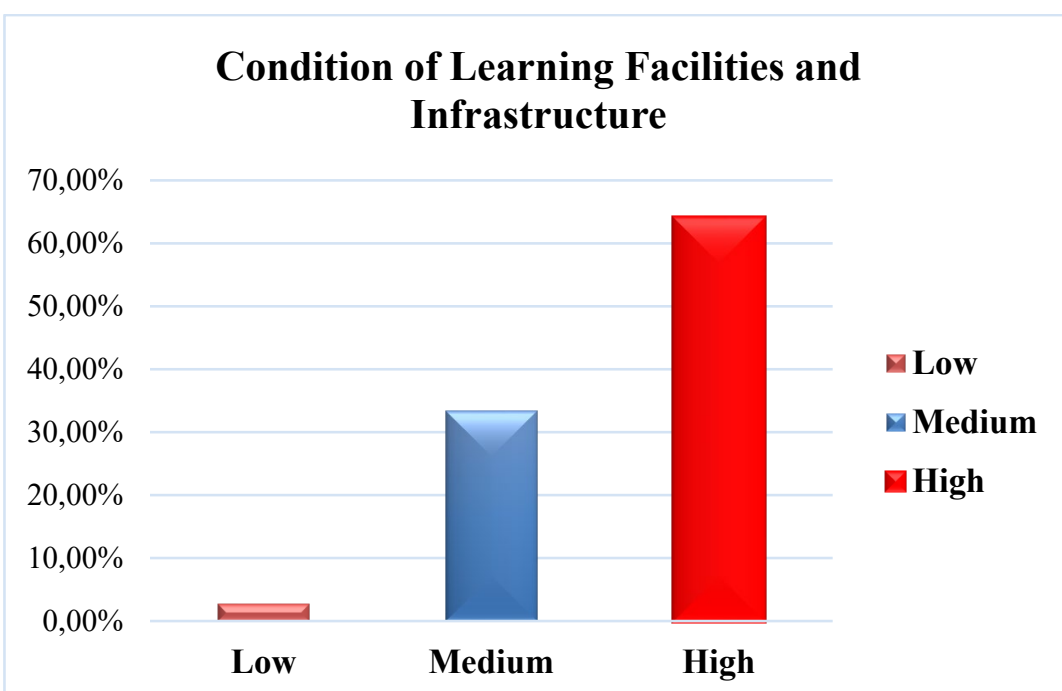

Figure 3. Graph of Frequency Distribution of Learning Facilities and Infrastructure Conditions

Based on the results of the analysis of the condition of facilities and infrastructure, it is known that as many as two respondents stated that the condition of the facilities and infrastructure used in the distance learning process was in the low category with a percentage of $2.67 \% .25$ respondents gave answers in the medium category with a percentage of $33.33 \%$. A total of 48 respondents stated that facilities and infrastructure in schools were in the high category with a percentage of $64 \%$. These results indicate that the condition of existing facilities and infrastructure in SMK Negeri 2 Makassar and SMK Negeri 10 Makassar is in the high category in supporting the implementation of distance learning.

\section{Learning Conditions}

The data obtained were processed using descriptive analysis. The results of descriptive analysis for the conditions of learning in SMK Negeri 2 Makassar and SMK Negeri 10 Makassar during the distance learning period can be seen in Table 7 . The data from the descriptive analysis were then substituted into intervals to determine the criteria and frequency distribution of the respondent's answers. The results can be seen in Table 8.

Based on Table 8, it is known that two respondents from SMK Negeri 2 Makassar and SMK Negeri 10 Makassar or as much as $2 \%$ stated that the condition of learning during the new normal Covid-19 is in a low category. A total of 50 respondents, or $67 \%$, stated that the learning conditions were in the medium category, and as many as 23 respondents or $31 \%$ were in the high category. These results indicate that the learning conditions at SMK Negeri 2 Makassar and SMK Negeri 10 Makassar are in the medium category with a percentage of $67 \%$.

Table 7. The Results of the Descriptive Analysis of Learning Conditions

\begin{tabular}{cccccc}
\hline Number of Respondents & Mean $(\mu)$ & Std. deviation $(\sigma)$ & Range & Minimum & Maksimum \\
\hline 75 & 17,5 & 3,5 & 17 & 11 & 28 \\
\hline
\end{tabular}


Figure 4 shows that the learning conditions during a Pandemic Covid-19 at SMK Negeri 2 and SMK Negeri 10 Makassar Makassar based on data from respondents in the middle category that is equal to $67 \%$.

Table 8. Frequency Distribution of Learning Conditions

\begin{tabular}{ccccc}
\hline Formula & Interval & Category & Frequency & Percentage \\
\hline $\mathrm{X}<\{17,5-1,0(3,5)\}$ & $\mathrm{X}<14$ & Low & 2 & $2 \%$ \\
$\{17,5-1,0(3.5)\} \leq \mathrm{X}<\{17,5+1,0(3,5)\}$ & $14 \leq \mathrm{X}<21$ & Medium & 50 & $67 \%$ \\
$\{17,5+1,0(3,5)\} \leq \mathrm{X}$ & $21 \leq \mathrm{X}$ & High & 23 & $31 \%$ \\
& & & & $100 \%$ \\
\hline
\end{tabular}

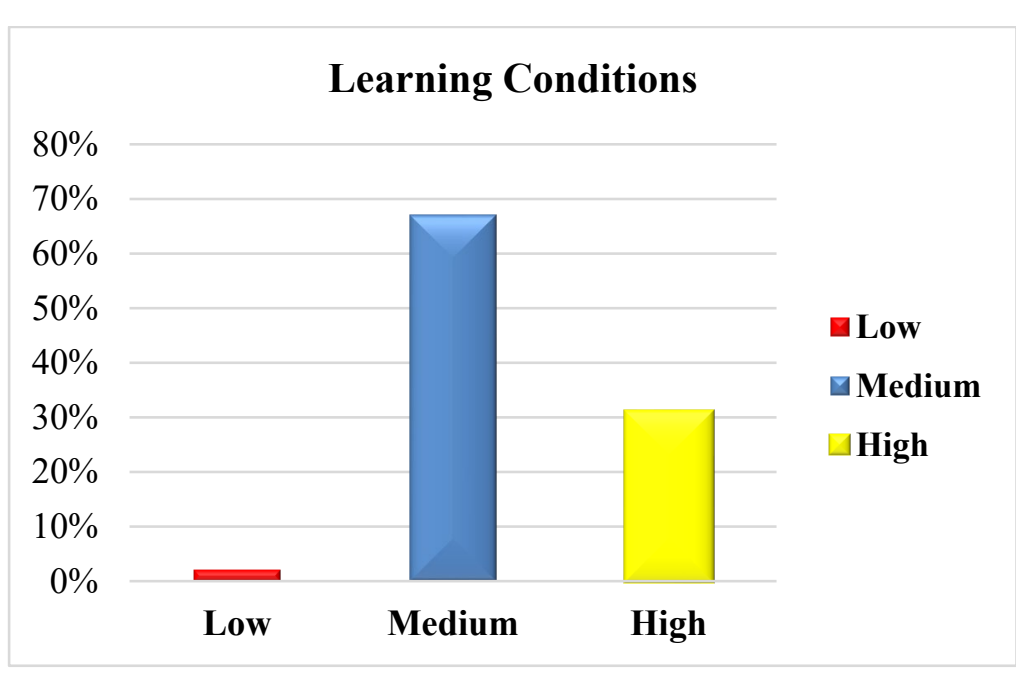

Figure 4. Graph of Frequency Distribution of Learning Conditions

\section{Learning Media Needs to Support Distance Learning}

The indicator for learning media needs in the form of an IoT-based sensor trainer consists of 7 question items related to the need for a media that is able to overcome obstacles in practical learning during the Covid-19 Pandemic, especially on sensor material. It is expected that students in distance learning, understanding, and knowledge of the characteristics of sensor components remain able to keep up with developments in the industrial world. Analysis of the needs of the media needs of 75 respondents consisting of teachers and students obtained the questionnaire data as shown in Table 9.

The descriptive data in Table 9 is then substituted into the interval table to determine each respondent's answer category. The frequency distribution results on the needs of learning media can be seen in Table 10. Based on the frequency distribution table for learning media needs, it can be seen that 21 respondents, or $28 \%$ of the total respondents, stated that the learning media needs were in the medium category, and 54 respondents, or $72 \%$, stated that the need for IoT-based learning media on sensor practice materials to support distance learning far in the high category. This shows that both teachers and students need the level of media needed in practical learning during the Covid19 pandemic.

Table 9. The Results of the Descriptive Analysis of Learning Media Needs

\begin{tabular}{cccccc}
\hline Number of Respondents & Mean $(\mu)$ & Std. deviation $(\sigma)$ & Range & Minimum & Maksimum \\
\hline 75 & 17,5 & 3,5 & 14 & 14 & 28 \\
\hline
\end{tabular}


Table 10. Frequency Distribution of Learning Media Needs

\begin{tabular}{ccccc}
\hline Formula & Interval & Category & Frequency & Percentage \\
\hline $\mathrm{X}<\{17,5-1,0(3,5)\}$ & $\mathrm{X}<14$ & Low & 0 & $0 \%$ \\
$\{17,5-1,0(3.5)\} \leq \mathrm{X}<\{17,5+1,0(3,5)\}$ & $14 \leq \mathrm{X}<21$ & Medium & 21 & $28 \%$ \\
$\{17,5+1,0(3,5)\} \leq \mathrm{X}$ & $21 \leq \mathrm{X}$ & High & 54 & $72 \%$ \\
& & & & $100 \%$ \\
\hline
\end{tabular}

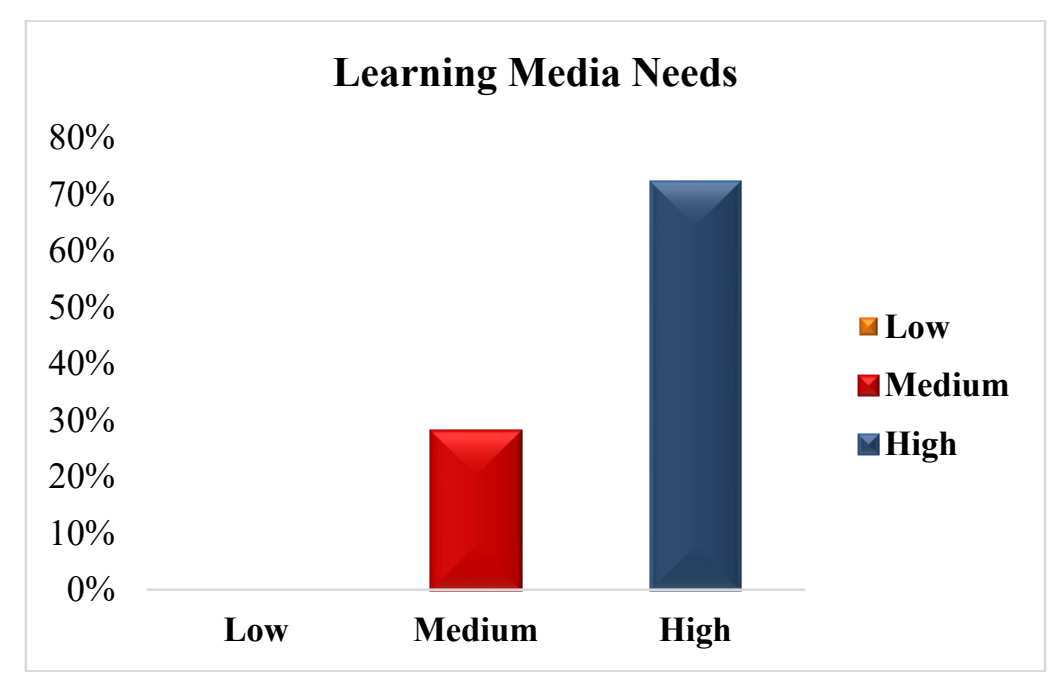

Figure 5. Graph of Frequency Distribution of Learning Media Needs

Discussion

The need for learning media during the Covid-19 Pandemic, which requires learning activities to be carried out at home, is very important. IoT technology is very helpful in the development of learning, especially in remote practicums that can be carried out boldly by utilizing the internet network. The same thing has been done by Kalashnikov et al. (2017) with the addition of cameras and communication devices by telemetry and IoT so that the implementation of remote practicum in the laboratory can be carried out. Another benefit of using IoT in remote practicum is that it can trigger students to actively participate in the process of creating their own IoT projects, increase student motivation and encourage them to learn and solve problems from the outside world (Guerra et al., 2017). The experiment conducted by Idhar et al. (2021) with the IoT trainer can also be carried out in the laboratory by implementing an application interface to give commands to devices connected to the internet in the trainer. Previous research examples will increase the importance of using IoT technology in laboratory practicums, especially during the Covid-19 Pandemic.

Based on the study results, it was found that the percentage of facilities and infrastructure supporting IoT-based distance learning was in the high category. One of the main facilities needed in distance learning is the availability of adequate internet and electronic or devices that support online learning (Rahayu \& Haq, 2020). Online learning is the main solution for education in dealing with the Covid-19 Pandemic. Still, several conditions must be improved to carry out distance learning effectively, including networks, competencies, and student abilities (Alperi et al., 2021). Hermawan (2021) added the need for improvements in terms of comfort, infrastructure, and absorption of knowledge that can provide a holistic experience to make it easier for students to learn and gain knowledge.

In addition to the availability of facilities for distance learning, teachers and students must have competence in the use of technology. Based on the research results, Darabi et al. (2006) found significant characteristics of distance teaching, namely interaction with learners and the need for technology and logistics. At the same time, Thach and Murphy (1995) revealed several competencies that describe the importance of technical and communication skills in distance learning, such as interpersonal communication, teamwork, and basic knowledge of technology.

The main requirement for developing IoT-based media is mastery of technology. Based on the IoT architecture, a physical layer is a number of sensors that detect and collect the surrounding 
information environment Sethi and Sarangi (2017), so it is important to know the characteristics of each sensor. IoT supports a number of sensors connected to each other via the internet. The development of the media trainer in this study adopted several types of sensors connected to a microcontroller that supports the internet network via a wifi connection. So that the monitoring process of reading sensor values can be done through applications on Android or web browsers, IoT technology will turn real objects into intelligent virtual objects (Saini et al., 2020).

\section{CONCLUSION}

Based on preliminary research results on the need for IoT-based learning media in censorship practices at SMK Negeri 2 Makassar and SMK Negeri 10 Makassar to support the implementation of distance learning during the Covid-19 Pandemic, it can be concluded as follows: 1.) The results of the analysis of the availability of facilities and infrastructure for media development IoT-based learning to support distance learning during the Covid-19 Pandemic at SMK Negeri 2 Makassar and SMK Negeri 10 Makassar is in the high category with a percentage of $64 \%$; 2.) Learning conditions, especially in practicum subjects during the Covid-19 Pandemic, based on the score of the questionnaire results were in the low category with a percentage level of $67 \%$; and 3.) The results of the analysis of the need for IoT-based sensor trainer learning media to support distance learning are very much needed in learning. This is shown from the results of the analysis of respondents' answers who are in the high category, with a percentage reaching $72 \%$ of the total respondents' answers. Based on the results obtained, the potential for developing IoT-based sensor trainer learning media is very large, especially in sensor practicum subjects. This is supported by an adequate level of facilities and infrastructure from each school that supports the use of Internet of Things (IoT) technology. The results of this study can also be used as a basis for teachers in developing media trainers in other IoT-based practical subjects.

\section{REFERENCES}

Aiken, L. R. (1985). Three coefficients for analyzing the reliability and validity of ratings. Educational and Psychological Measurement, 45(1), 131-142. https://doi.org/10.1177/0013164485451012

Allen, I. E., Seaman, J., \& Garrett, R. (2007). Blending in: The extent and promise of blended education in the United States. Sloan Consortium. https://files.eric.ed.gov/fulltext/ED529930.pdf

Alperi, M., Riyanto, R., Sapri, J., Alexon, A., \& Handayani, D. (2021). Analysis of the implementation of distance learning in the COVID-19 -Pandemic new normal era. International Journal of Asian Education, 2(2), 120-128. https://doi.org/10.46966/ijae.v2i2.172

Arifin, Z., \& Zuhrie, M. S. (2015). Pengembangan trainer dan jobsheet mikrokontroler sebagai media pembelajaran pada mata pelajaran perekayasaan sistem kontrol di Jurusan Elektronika Industri SMK Negeri 1 Bangil. Jurnal Pendidikan Teknik Elektro, 5(1), 383-388. https://ejournal.unesa.ac.id/index.php/jurnal-pendidikan-teknik-elektro/article/view/14057

Azwar, S. (2010). Metode penelitian. Pustaka Pelajar.

Azwar, S. (2016). Metode penelitian. Pustaka Belajar.

Darabi, A. A., Sikorski, E. G., \& Harvey, R. B. (2006). Validated competencies for distance teaching. Distance Education, 27(1), 105-122. https://doi.org/10.1080/01587910600654809

Guerra, H., Garcia, A. M., Gomes, L. M., \& Cardoso, A. (2017). An IoT remote lab for seismic monitoring in a programming course.4th Experiment@International Conference, 129-130. https://doi.org/10.1109/EXPAT.2017.7984361 
Hariyadi, A., \& Kholis, N. (2015). Pengembangan trainer mikrokontroler sebagai media pembelajaran di SMK Negeri 1 Sidoarjo. Jurnal Pendidikan Teknik Elektro, 4(3), 669-673. https://jurnalmahasiswa.unesa.ac.id/index.php/17/article/view/12287

Hariyanto, H., Aribowo, D., \& Fatkhurrokhman, M. (2020). Pengembangan media pembelajaran trainer kit pengendali motor 3 phase pada mata pelajaran instalasi motor listrik di SMKN 4 Kota Serang. JURNAL PENDIDIKAN FISIKA DAN KEILMUAN (JPFK), 5(1), 1-7. https://doi.org/10.25273/jupiter.v5i1.6223

Hasanah, N., Mahali, M. I., \& Wulandari, B. (2018). Pengembangan trainer internet of things sebagai media pembelajaran pada mata kuliah internet of things. Elinvo (Electronics, Informatics, and Vocational Education), 3(2), 19-29. https://doi.org/10.21831/elinvo.v3i2.20353

Hermawan, D. (2021). The rise of e-learning in COVID-19 Pandemic in private university: Challenges and opportunities. IJORER: International Journal of Recent Educational Research, 2(1), 86-95. https://doi.org/10.46245/ijorer.v2i1.77

Idhar, I., Purnamawati, P., Tangking, R., \& Ruslan, R. (2021). The use of internet of things (iot) to produce trainer and remote lab learning media. Journal of Physics: Conference Series, 1810(1), 012003. https://doi.org/10.1088/1742-6596/1810/1/012003

Jarillo, M. P., Pedraza, L., \& Ger, P. M. (2019). Work-in-progress: Improving online higher education with virtual and remote labs. 2019 IEEE Global Engineering Education Conference (EDUCON), 1136-1139. https://doi.org/10.1109/EDUCON.2019.8725272

Kalashnikov, A., Zhang, H., Jennings, J., \& Abramriuk, M. M. (2017). Remote laboratory: using Internet-of-Things (IoT) for e-learning. In Comparison of the responsiveness of ultrasonic oscillating temperature sensors (UOTSes) and conventional sensors to temperature inflection points (pp. 43-46). http://shura.shu.ac.uk/15845/1/Section_3_Kalashnikov_IoT_E-learning.pdf

Lalima, L., \& Dangwal, K. L. (2017). Blended learning: an innovative approach. Universal Journal of Educational Research, 5(1), 129-136. https://doi.org/10.13189/ujer.2017.050116

Mariana, M. (2020). Comparation of teacher center learning and student center learning approach to better understanding in mining regulation study. Jurnal Ilmiah PPSDM GEOMINERBA, 5(1), 1-8. https://doi.org/10.13140/RG.2.2.29424.48643

Marpaung, D. N., \& Azzajjad, M. F. (2020). The effectiveness of student centre learning in experiment method on acid and base solution to increase student achievement. Journal of Applied Science, Engineering, Technology, and Education, 2(1), 32-36. https://doi.org/10.35877/454RI.asci2156

Nurrita, T. (2018). Pengembangan media pembelajaran untuk meningkatkan hasil belajar siswa. Misykat: Jurnal Ilmu-Ilmu Al-QurAEan, Hadist, Syariah Dan Tarbiyah, 3(1), 171-187. https://doi.org/10.33511/misykat.v3n1.171

Purnamawati, P., Akil, M., \& Nuridayanti, N. (2021). A feasibility study of sensor and transducer trainers as a learning media towards electronics engineering's students. Journal of Physics: Conference Series, 1810(1), 012051. https://doi.org/10.1088/1742-6596/1810/1/012051

Rahayu, A. D., \& Haq, M. S. (2020). Sarana dan prasarana dalam mendukung pembelajaran daring pada masa Pandemi Covid-19. Journal Inspirasi Manajemen Pendidikan, 9(1), 186-199. https://ejournal.unesa.ac.id/index.php/inspirasi-manajemen-pendidikan/article/view/38623

Rahayu, M., Hariyanto, T., \& Fadhlan, M. Y. (2020). IoT trainer kit training for vocational school teachers as preparation towards the 4.0 industry era. REKA ELKOMIKA: Jurnal Pengabdian Kepada Masyarakat, 1(2), 98-110. https://doi.org/10.26760/rekaelkomika.v1i2.98-110

Rahmadiyah, I. P., \& Sumbawati, M. S. (2014). Pengembangan media pembelajaran trainer elektronika digital untuk mata pelajaran teknik elektronika dasar. JPTE : Jurnal Pendidikan 
Teknik

Elektro,

$4(1)$

$145-152$.

https://jurnalmahasiswa.unesa.ac.id/index.php/17/article/view/10399

Saini, K. S., Shrivastva, A., Walia, K., \& Singh, R. (2020). IoT architecture, working \& application: a review. International Journal of Advance Science and Technology, 29(10), 2670-2678. http://sersc.org/journals/index.php/IJAST/article/view/16972

Sethi, P., \& Sarangi, S. R. (2017). Internet of things: Architectures, protocols, and applications. Journal of Electrical and Computer Engineering, 2017. https://doi.org/10.1155/2017/9324035

Thach, E. C., \& Murphy, K. L. (1995). Competencies for distance education professionals. Educational Technology Research and Development, 43(1), 57-79. https://doi.org/10.1007/BF02300482

Yaumi, M. (2018). Media \& teknologi pembelajaran (S. F. S. Sirate (ed.); 1st ed.). PrenadaMedia Group.

https://books.google.com/books?hl=en\&lr=\&id=2uZeDwAAQBAJ\&oi=fnd\&pg=PR5\&dq $=$ Media + dan + Teknologi + Pembelajaran + Yaumi\&ots $=$ RE1 A8gyblT\&sig $=$ umoR3vVMFEv Uf3hfn6ZibVoWxgk

Zaus, M. A., Krismadinata, K., Syah, N., Jalinus, N., Wulansari, R. E., \& Islami, S. (2019).

Development instructional media on static and dynamic electrical based on android as student center learning media. International Journal of Scientific and Technology Research, 8(11), 3589-3591. http://www.ijstr.org/final-print/nov2019/DevelopmentInstructional-Media-On-Static-And-Dynamic-Electrical-Based-On-Android-As-StudentCenter-LearningMedia.pdf 